\title{
Modeling the Wintering Habitat Distribution of Oriental Honey Buzzards in West Java Indonesia with Satellite Tracking Data Using Logistic Regression
}

\author{
Syartinilia $^{1 *}$, Yeni Aryati Mulyani ${ }^{2}$, Afra Donatha Nimia Makalew ${ }^{1}$, Hiroyoshi Higuchi ${ }^{3}$ \\ ${ }^{1}$ Department of Landscape Architecture, Faculty of Agriculture, Bogor Agricultural University (IPB), Kampus IPB Dramaga, Bogor, \\ Indonesia \\ ${ }^{2}$ Department of Forest Resources Conservation and Ecotourism, Faculty of Forestry, Bogor Agricultural University (IPB), Kampus IPB \\ Dramaga, Bogor, Indonesia \\ ${ }^{3}$ Research and Education Center for Natural Sciences, Keio University, Hiyoshi, Yokohama, Kanagawa, Japan
}

\section{ARTICLE INFO}

Article history:

Received April 10, 2019

Received in revised form September 13, 2021

Accepted September 23, 2021

\section{KEYWORDS:}

Logistic regression,

Migratory raptor,

Pernis ptilorhynchus,

RAMAS GIS,

Satellite-tracking,

Wintering habitat

\begin{abstract}
Oriental honey buzzards (OHBs, Pernis ptilorhynchus) are one of migratory raptor from Japan to Indonesia which is widely recognized as indicator species reflecting the conditions of their habitat. Since 2003 , OHBs have been satellitetracked in their wintering grounds in Indonesia. Less information available on wintering areas in the west Java, which hampers the OHB conservation efforts. This paper proposes a new approach for predicting the probability models of the wintering habitat distribution of $\mathrm{OHBs}$ with the presence data derived from satellite tracking using logistic regression analysis coupled with RAMAS GIS. This spatial model was locally constructed from the data concerning Talaga Bodas and its surrounding areas and extrapolated for the entire West Java region. The best predicted probability model successfully characterized the distribution of the OHB wintering habitat using slope (25-40\%), elevation (0-300 $\mathrm{m}$ and $>1,000 \mathrm{~m}$ ), and land cover (forest, paddy field, and water body). The extrapolation model generated potential areas of the wintering habitat distribution covering an area of $3013.13 \mathrm{~km}^{2}(8.11 \%$ of West Java). These areas were predominantly located outside the protected areas $(94.04 \%)$. The modeling approach proposed herein may be used to study other migratory species that are tracked using satellite or other navigation technologies.
\end{abstract}

\section{Introduction}

Many migratory raptors that breed in the eastern Palearctic area spend their winter in Indonesia (Germi 2005). Of the 56 species of migratory raptors in Asia, 19 species have been recorded in Indonesia (Zalles and Bildstein 2000). Raptors are quite sensitive to changes in the ecosystem and vulnerable to environmental pollution. Therefore, it is widely recognized that they are indicator species reflecting the conditions of their habitat. The survival of migratory raptors depends on how well they cope in 3 key environments: breeding area, wintering area, and areas along the migration route (Bildstein 2006). They are perhaps more vulnerable than most resident species because their survival depends on these environments. In Indonesia, raptors are threatened by severe habitat

* Corresponding Author

E-mail Address: syartinilia@apps.ipb.ac.id loss, forest conversion, fragmentation, and poaching (Syartinilia and Tsuyuki 2008). Poaching is one of the biggest threats in parts of Indonesia even though all raptor species are protected by Indonesian law (UU No. 5 1990) and Indonesian Art (PP Nos. 7 and 8 1999).

Oriental honey buzzards (OHBs, Pernis ptilorhynchus) are migratory raptors that live in forests, arable land, and semi-deserts (Ferguson and Christie 2005). Their breeding grounds are in southern Siberia, northeastern China, Japan, and Korea; however, they migrate south during the winter (Ornithological Society of Japan 2000). A previous study investigated 49 OHBs in Japan that were mounted with transmitters and satellite-tracked since 2003 (Syartinilia et al. 2015). While satellite tracking is used to record long-distance movements of animals (Cohn 1999; Webster et al. 2002; Higuchi and Pierre 2005), it is also an effective method for studying local movements. We found that $47 \%$ of the 49 OHBs visited Borneo during winter; however, only 
4\% ( 3 OHBs) used the Java Island for their wintering site. Moreover, only one $\mathrm{OHB}$ has a wintering site in West Java, namely in Telaga Bodas and its surroundings. Furthermore, there is considerably less information available on wintering areas in the West Java, which hampers the OHB conservation efforts. Given Java's rapid development, there is a certain urgency for obtaining information on the wintering habit distribution of OHBs to secure the survival of this species by effectively managing their habitat.

Species distribution models (SDMs) has several methods for predicting species occurrence, and each method has strengths and weaknesses. The generalized linear models (GLMs), especially logistic regression within a GIS, are the most preferred modelling techniques used for predicting species distributions (Guisan et al. 2002; Engler et al. 2004; Piorecky and Prescott 2006; Syartinilia and Tsuyuki 2008; Barradas et al. 2012). The other most popular method is Maximum Entropy (Maxent) which use a presence-only approach (Merow et al. 2013; Phillips et al. 2017). The weaknesses of MaxEnt are technically taking more time to consider the appropriate data inputs and how to set the software (Merow et al. 2013), while Maxent performs better than logistic regression when the sample size is small (Phillips and Dudík 2008). The logistic regression performs better suited for fine-scale datasets than MaxEnt (Huang and Frimpong 2015). However, logistic regression requires both the presence and absence data for modelling species distribution, which is particularly challenging when dealing with migratory birds with massive data from satellite tracking. Given the abundance of the presence data from satellite tracking, care must be taken while generating the pseudo-absence data to avoid commission/omission errors. Therefore, this study proposes a new approach for predicting the probability models of the wintering habitat distribution of OHBs in West Java with the presence of data derived from satellite tracking using logistic regression (LR) analysis coupled with GIS.

This study aimed to 1 ) propose a probability model of the wintering habitat distribution of OHBs in and around Talaga Bodas, West Java, Indonesia, from 2003 to 2006 with the presence data derived from satellite tracking using LR analysis coupled with GIS, 2) identify the landscape characteristics associated with the wintering habitat selection of OHBs based on the LR model, and 3) extrapolate the predicted probability model of the OHB distribution in West Java, which may be used for managing the wintering habitat of OHBs in West Java.

\section{Materials and Methods}

\subsection{Study Area}

The focus of this study was to predict a probability model of the wintering habitat distribution of OHBs in Talaga Bodas and its surrounding areas. Talaga Bodas is located in the Garut and Tasikmalaya districts of West Java, Indonesia (latitude $S 6^{\circ} 36^{\prime} 00^{\prime \prime}-S 7^{\circ} 21^{\prime} 00^{\prime \prime}$, longitude $\mathrm{E} 107^{\circ} 35^{\prime} 00^{\prime \prime}-\mathrm{E} 108^{\circ} 21^{\prime} 00^{\prime \prime}$, encompassing $472618.71 \mathrm{ha}$ ). The model was then extrapolated to the entire West Java region (Figure 1). Talaga Bodas Nature Reserve (285 ha) and Talaga Bodas Natural Recreation Park (27.8 ha) were included in the study area. The natural features of the study area include a caldera (11 ha), 3 hot springs, and geothermal energy. The geothermal power plant in Karaha Bodas, owned by PT Pertamina Geothermal Energy, has been explored to support Java, Madura, and Bali with as much as $30 \mathrm{MW}$ of electricity. The average annual temperature on the study area varies between $28^{\circ} \mathrm{C}$ and $30^{\circ} \mathrm{C}$. The mean annual rainfall is $1,321 \mathrm{~mm}$, which with respect to the climate type is categorized as type $C$ based on the Schmidt and Fergusson system. Analysis of the image classification of Talaga Bodas and its surrounding areas captured using ALOS AVNIR-2 on October 29,2009 showed that agricultural land and forests covered $65 \%$ and $21 \%$ of these areas, respectively.

\subsection{Presence Data}

This study proposes a new approach for predicting a probability model of the wintering habitat distribution OHBs using the presence data derived from satellite tracking. The accuracy of the location estimated using the Argos system was categorized by a location class (LC; Argos 2016). All LCs were ranked in the increasing order of accuracy: $Z$ (least accurate), $B, A, 0,1,2$, and 3 (most accurate). Only LCs $0-3$ were used in data analysis; LCs Z, A, and B were largely removed from the system although the data of LCs $A$ and B were used when these LCs were spatially and temporally close to LCs $0-3$. The location errors of LCs 0-3 are as follows: $1,000 \mathrm{~m}, 350-1,000 \mathrm{~m}, 150-350$ $\mathrm{m}$, and $<150 \mathrm{~m}$, respectively. The area was defined as a wintering site if OHBs stayed at least $24 \mathrm{~h}$ within an area that is $<30 \mathrm{~km}$ in diameter (Higuchi et al. 2005).

The satellite-tracking data of one adult of $\mathrm{OHB}$ from a breeding site in the Nagano Prefecture, Japan in period of 2003 to 2005 to the wintering site in Talaga Bodas and the surrounding areas, Indonesia were used in this study (Figure 2). Approximately 522 wintering sites from these areas were identified 

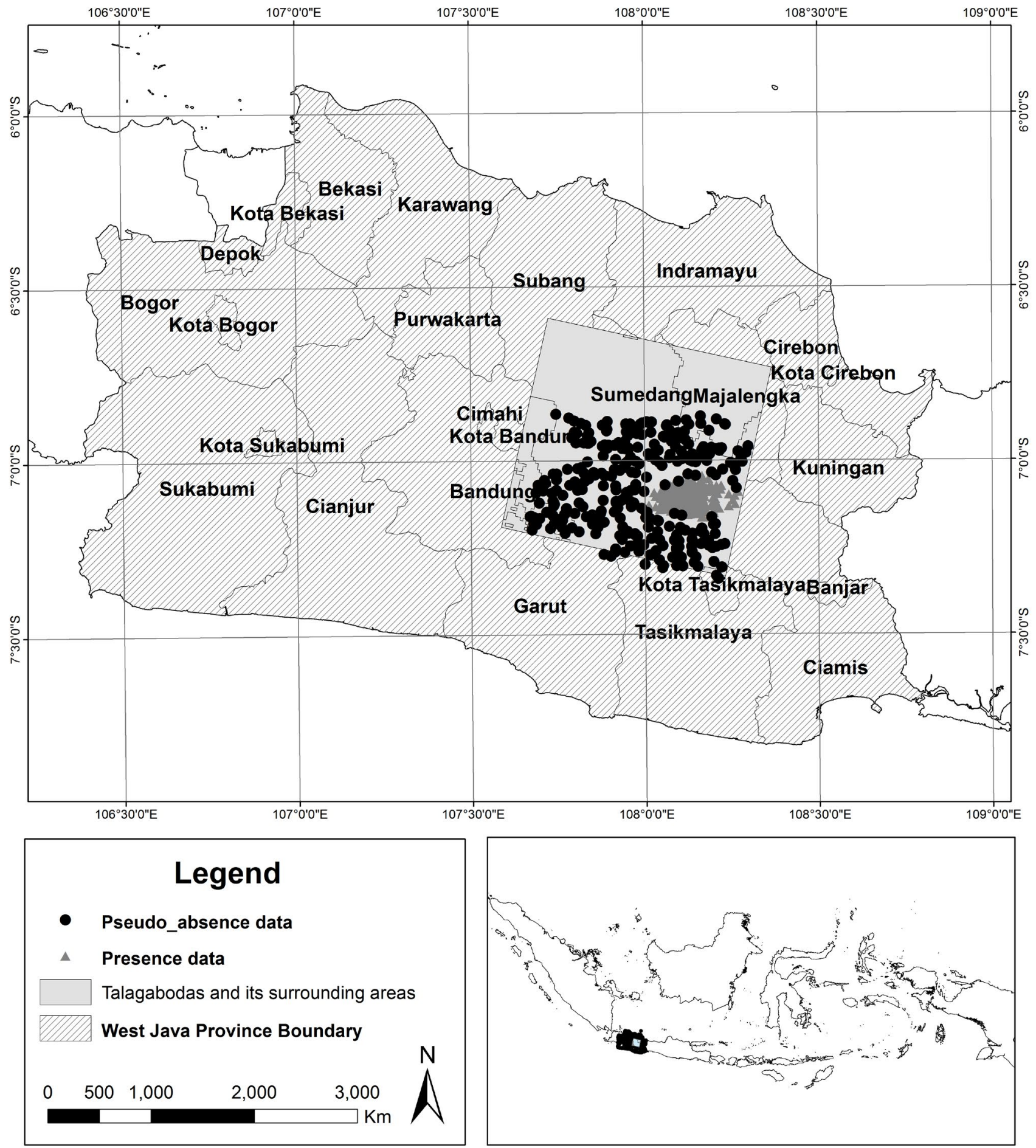

Figure 1. Map of West Java showing the study area

and analyzed. In previous study, the fixed-kernel density technique was used to identify the core and edge habitats of wintering sites. Core habitats are defined as areas with OHB's satellite-tracking data density higher than that in edge habitats (Syartinilia et al. 2015). The spatial distribution of the core and edge habitats, were estimated using a 50\% fixed kernel (FK_50\%) and a 95\% fixed kernel (FK_95\%), respectively. The fixed-kernel density, regarded as the most powerful home-range estimator (Worton 


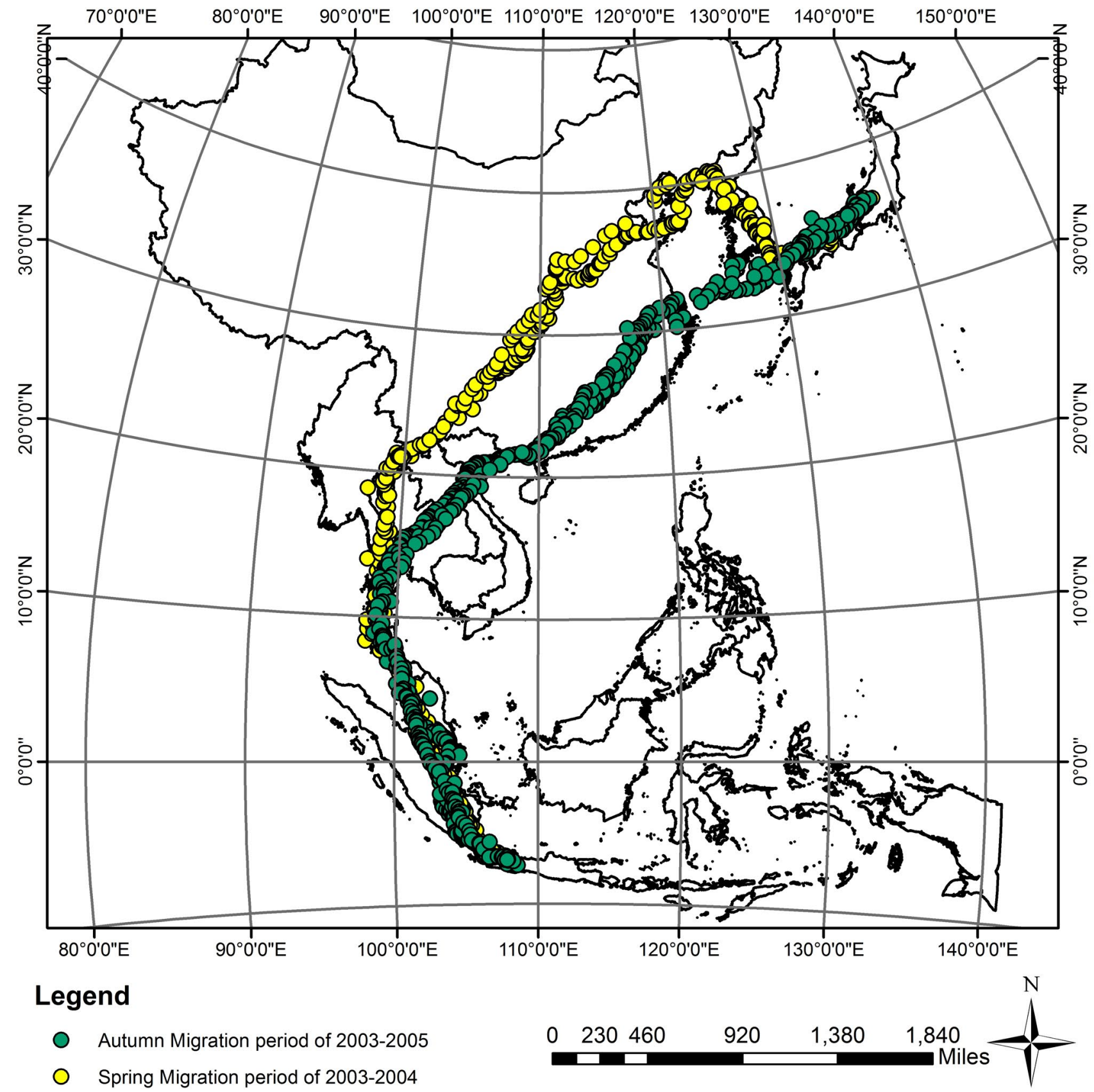

Figure 2. Satellite tracking data from one individual Oriental honey buzzard (OHB) during 2003-2005

1989; Seaman and Powell 1996; Wauters et al. 2007) that is often used for habitat selection studies (Mace et al. 1996; Mace and Waller 1997; Kenward et al. 2001; McLoughlin et al. 2002; Lyons et al. 2003), successfully delineated the core and edge habitats of the wintering sites of OHBs in Borneo (Syartinilia et al. 2015). Using this technique, 368 wintering sites or $\sim 70 \%$ of satellite tracking data were located in the core habitat, while the remaining data were located in the edge habitat. Approximately 250 wintering sites in the core habitat were used for model creation, whereas the remaining 118 wintering sites were used for model validation.

Field surveys were conducted in 2 stages. The first stage was conducted in Talaga Bodas and its surrounding areas during the winter season. The second stage was conducted in the Nagano Prefecture, Japan, during breeding season. The field survey included the following activities: (1) recording the occurrence of $\mathrm{OHB}$ and determining the condition and 
activity of birds, (2) plotting all the detection points on the location map and recording their geographic location using GPS, (3) providing an overview of each survey site and characterizing the habitat, (4) capturing digital photographs of the survey area and OHB activities, (5) interviewing local residents near Talaga Bodas and its surrounding areas and key individuals from the NGO of Raptor Indonesia, and (6) discussing $\mathrm{OHB}$ with a number of Japanese researchers.

\subsection{Pseudo-absence Data}

The main difficulty in applying GLM is when the absence data are not available. Generating pseudoabsence data in place of absence data is one solution for resolving this issue (Stockwell and Peterson 2002a; Zaniewski et al. 2002; Engler et al. 2004; Pearce and Boyce 2006; Syartinilia and Tsuyuki 2008). The easiest way to select pseudo-absences is to randomly generate them in the study area (Hirzel et al. 2001; Zaniewski et al. 2002). However, this method may possibly generate an error in predicting the absence of species in areas actually favored by the species.

To address this issue, herein, a new approach considering a random sampling point inside the delineated edge habitat was proposed for generating pseudo-absence data. Edge habitat, as defined in a previous study, is an area that surrounds the core habitat, acts as its buffer, and maintains the quality of its core habitat (Syartinilia et al. 2015). The pseudoabsence data were obtained through random selection of 250 wintering sites within the edge habitat using Hawth's Tools (http://www.spatialecology.com) as a free extension for the spatial ecology tool for animal studies in ArcGIS 9.3.1.

\subsection{Environmental Variables and GIS Coverage}

Environmental variables were selected based on the ecology of migratory raptors that depend on their habitat requirements, including food availability (Hutto 1985) and thermal wind (Bruderer et al. 1994). In total, 3 raster maps (elevation, slope, and land cover) were used for derivating all environmental variables, which were then converted into Euclidean distance images. The raster layers of the slope and elevation were obtained from the ASTER Global Digital Elevation Model (ASTER GDEM) with a resolution of $30 \times 30 \mathrm{~m}$ (available at http://www.gdem.aster.ersdac.or.jp/). Land cover maps were derived from 2 images: ALOS AVNIR-2 with scene identity (ALAV2A200433740 with 10-m resolution captured on October 29, 2009) for model creation and LANDSAT 7 path/row (121/065 and $122 / 065$ captured on October 13, 2009) for model extrapolation. All images that were analyzed using supervised classification with the maximum likelihood method were classified according to 7 land cover classes: water body, paddy field, dryland farming, build-up area, shrub, plantation, and forest. Overall accuracy and Kappa accuracy for both land cover maps were more than $85 \%$.

The environmental variables comprised 11 terrain factors and 7 land cover factors (Table 1 ). All variables were presented in raster format (resolution: $30 \times 30$ $\mathrm{m}$ ) in the form of Euclidean distance images. First, a binary map of each elevation, slope, and land cover class was created. Then, it was converted into vector maps. Finally, the Euclidean distance was calculated. All processes were performed using ArcGIS 9.3.1 and ERDAS IMAGINE 9.1.

\subsection{Probability Model of the Wintering Habitat Distribution}

A multicolinearity test using variance inflation factor (VIF) and 2 independent sample t-tests ( $\alpha$ $<0.01$ ) were performed to determine which variables differed significantly between the $\mathrm{OHB}$ presence data

Table 1. Environmental variables used herein

\begin{tabular}{|c|c|c|}
\hline \multirow{6}{*}{$\begin{array}{l}\text { Parameter } \\
\text { Elevation }\end{array}$} & Environment variables & Abbreviation \\
\hline & $\begin{array}{l}\text { Nearest distance to the elevation: } \\
0-300 \mathrm{~m}\end{array}$ & DE1 \\
\hline & $\begin{array}{l}\text { Nearest distance to the elevation: } \\
300-500 \mathrm{~m}\end{array}$ & DE2 \\
\hline & $\begin{array}{l}\text { Nearest distance to the elevation: } \\
500-700 \mathrm{~m}\end{array}$ & DE3 \\
\hline & $\begin{array}{l}\text { Nearest distance to the elevation: } \\
700-1000 \mathrm{~m}\end{array}$ & DE4 \\
\hline & $\begin{array}{l}\text { Nearest distance to the elevation: } \\
>1000 \mathrm{~m}\end{array}$ & DE5 \\
\hline \multirow[t]{6}{*}{ Slope } & $\begin{array}{l}\text { Nearest distance to the slope: } \\
0-3 \%\end{array}$ & DS1 \\
\hline & $\begin{array}{l}\text { Nearest distance to the slope: } \\
3-8 \%\end{array}$ & DS2 \\
\hline & $\begin{array}{l}\text { Nearest distance to the slope: } \\
8-15 \%\end{array}$ & DS3 \\
\hline & $\begin{array}{l}\text { Nearest distance to the slope: } \\
15-25 \%\end{array}$ & DS4 \\
\hline & $\begin{array}{l}\text { Nearest distance to the slope: } \\
25-40 \%\end{array}$ & DS5 \\
\hline & $\begin{array}{l}\text { Nearest distance to the slope: } \\
>40 \%\end{array}$ & DS6 \\
\hline \multirow[t]{7}{*}{$\begin{array}{l}\text { Land } \\
\text { cover }\end{array}$} & $\begin{array}{l}\text { Nearest distance to the water } \\
\text { body }\end{array}$ & DWB \\
\hline & $\begin{array}{l}\text { Nearest distance to the paddy } \\
\text { field }\end{array}$ & DPF \\
\hline & $\begin{array}{l}\text { Nearest distance to the dryland } \\
\text { farming }\end{array}$ & DDF \\
\hline & $\begin{array}{l}\text { Nearest distance to the build-up } \\
\text { area }\end{array}$ & DBA \\
\hline & Nearest distance to the shrub & DSB \\
\hline & $\begin{array}{l}\text { Nearest distance to the } \\
\text { plantation }\end{array}$ & DPT \\
\hline & Nearest distance to the forest & DFT \\
\hline
\end{tabular}


and the OHB pseudo-absence data. This was followed by LR analysis using SPSS 15.0 (SPSS Inc.) with forward stepwise method to determine the probability of the occurrence of the wintering habitat. The LR function can be expressed as follows:

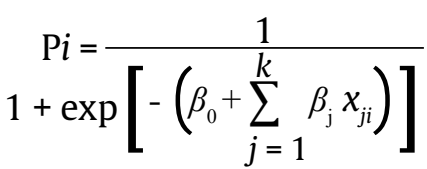

where $\mathrm{P} i$ is the probability, $x_{j}$ is the covariate, $i$ is the pixel, $\beta_{0}, \beta_{\mathrm{j}}$, and $c$ are the estimated coefficients, and $k$ is the number of covariates.

Selected independent variables were overlaid in RAMAS GIS v4.0 (Akcakaya and Root 2002) using the LR equation obtained for patch recognition. A threshold probability value of 0.5 , commonly used for predicting the species distribution (Manel et al. 1999; Bailey et al. 2002; Stockwell and Peterson 2002b; Syartinilia and Tsuyuki 2008), was used to identify a habitat patch. The model variability accounted for in Nagelkerke $\mathrm{R}^{2}$, an analog to $\mathrm{R}^{2}$ in ordinary least squares (OLS) regression (Peng et al. 2002; Piorecky and Prescott 2006; Syartinilia and Tsuyuki 2008), and the Hosmer-Lemeshow test were used to determine the feasibility of the model (Hosmer et al. 1997). Once the model was shown to be feasible, model validation was performed, followed by model extrapolation. Furthermore, 2 types of errors were encountered during model validation: the omission and commission errors (Boone and Krohn 1999; Ottaviani et al. 2004; Syartinilia and Tsuyuki 2008). An omission error occurs when an $\mathrm{OHB}$ wintering site identified as inappropriate is contradicted by satellite-tracking detection. The omission error rate of around $20 \%$ uses as a benchmark in the species distribution modelling of Javan Hawk-Eagle (Syartinilia and Tsuyuki 2008). Conversely, a commission error occurs when an area identified as the $\mathrm{OHB}$ wintering site is contradicted by the lack of satellite-tracking data. Following validation, the model was extrapolated to West Java to predict the $\mathrm{OHB}$ wintering habitat distribution for that entire region. Flow chart showing the spatial modeling of the OHB wintering habitat using logistic regression (Figure 3).

\section{Results}

\subsection{Probability Model of the Wintering Habitat Distribution}

The results of the 2 independent sample $t$-tests showed that 11 environmental variables significantly influenced wintering habitat distribution OHBs, but as summarized in Table 2, only 7 environmental variables with $\mathrm{p}$-value $<5 \%$ were important variables for the characteristics of the OHB wintering habitat: slope of 25-40\% (DS5), elevation of 0-100 m (DE1), elevation of 100-300 m (DE2), elevation greater than $1,000 \mathrm{~m}$ (DE5), forest (DFT), paddy field (DPF), and water body (DWB). The Hosmer-Lemeshow (98.7\%) and Nagelkerke $\mathrm{R}^{2}(85.4 \%)$ tests showed that the model was feasible. The final LR model can be expressed as follows:

$$
\begin{aligned}
& \mathrm{P} i=\frac{1}{1+\exp [-(-1.610(3.366(\mathrm{DS} 5)+4.304(\mathrm{DE} 1)-5.752} \\
& (\mathrm{DE} 2)-2.467(\mathrm{DFT})-0.914(\mathrm{DPF})+1.259(\mathrm{DWB}))+1
\end{aligned}
$$

The equations of LR model revealed predicted probability model for the wintering habitat distribution of OHBs in Talaga Bodas and its surrounding areas. Model validation revealed an omission error of $20.34 \%$ in which only 24 locality records from 118 of satellite data contradicted the model's classification of a habitat as being unsuitable. However, the model was $79.6 \%$ or 94 locality records are correct in predicting suitable $\mathrm{OHB}$ wintering habitats in Talaga Bodas and its surrounding areas. The omission error rate is acceptable because the model can accurately predict more than $75 \%$. The model did not focus on commission error since only 1 habitat patch was identified in the model.

\subsection{Model Extrapolation}

The extrapolation of model successfully predicted the wintering habitat distribution across the West Java region, which covers $\sim 3013.13 \mathrm{~km}^{2}$ or $8.11 \%$ of West Java (Figure 4 ). While $94.04 \%$ of suitable habitats were located outside protected areas, only $9.56 \%$ of suitable habitats $\left(179.57 \mathrm{~km}^{2}\right)$ were located inside national parks, nature reserves, nature recreation parks, grand forest parks, wildlife reserves, and game reserves (Table 3 ). 


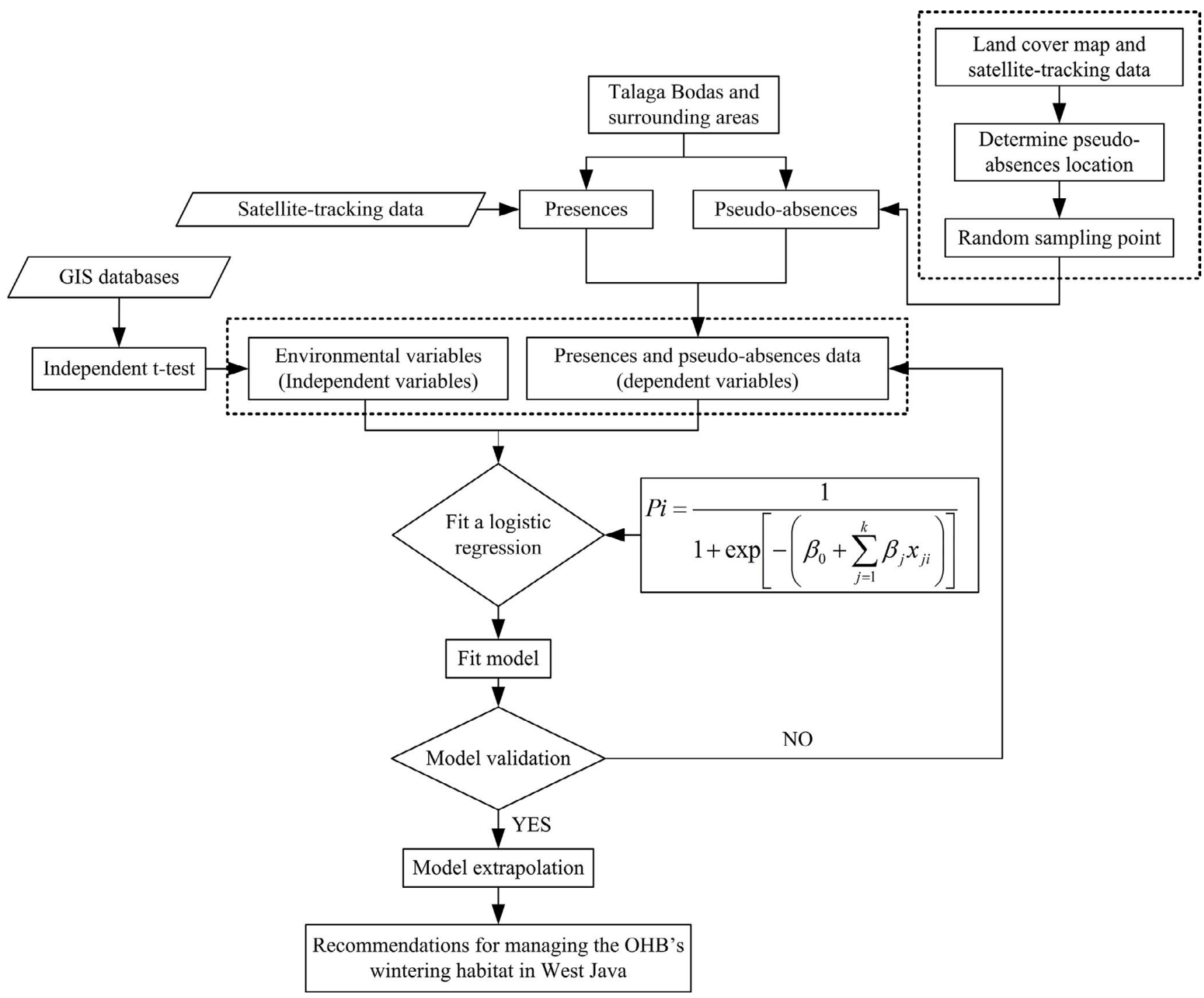

Figure 3. Flow chart showing the spatial modeling of the OHB wintering habitat using logistic regression

Table 2. Logistic regression results obtained using the forward stepwise method

\begin{tabular}{lcccc}
\hline Variable & Coefficient & p-value (sig) & Hosmer and lemeshow & Nagelkerke R \\
\hline Slope (25-40\%; DS5) & 3.366 & 0.000 & $86.2 \%$ & $94.0 \%$ \\
Elevation (0-100 m; DE1) & 4.304 & 0.000 & & \\
Elevation (100-300 m; DE2) & -5.752 & 0.000 & \\
Elevation (>1,000 m; DE5) & -2.811 & 0.002 & \\
Forest (DFT) & -2.467 & 0.013 & \\
Paddy field (DPF) & -0.914 & 0.011 & \\
Water body (DWB) & 1.259 & 0.034 & \\
Constant & -1.610 & 0.001 & & \\
\hline
\end{tabular}




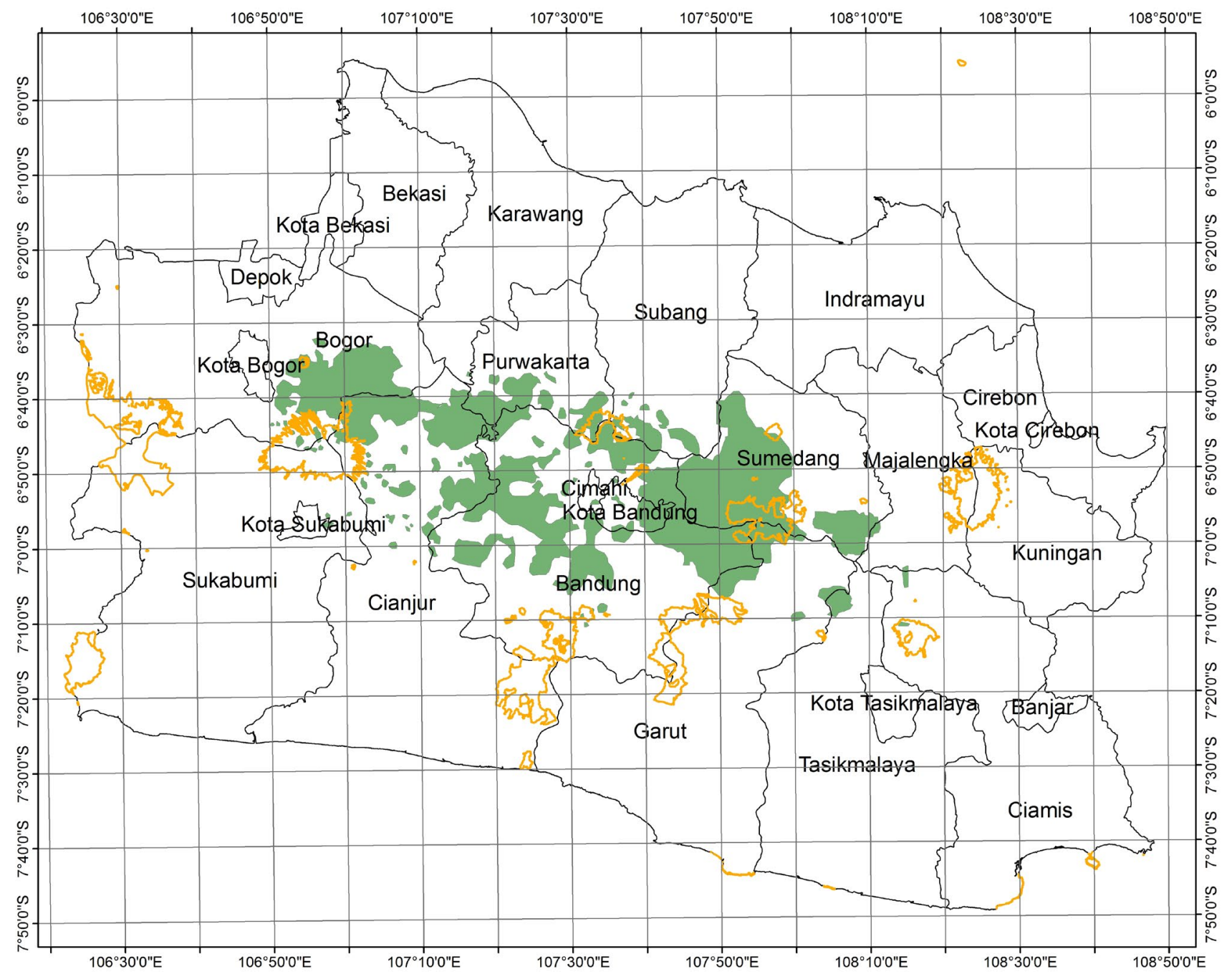

\section{Legend}
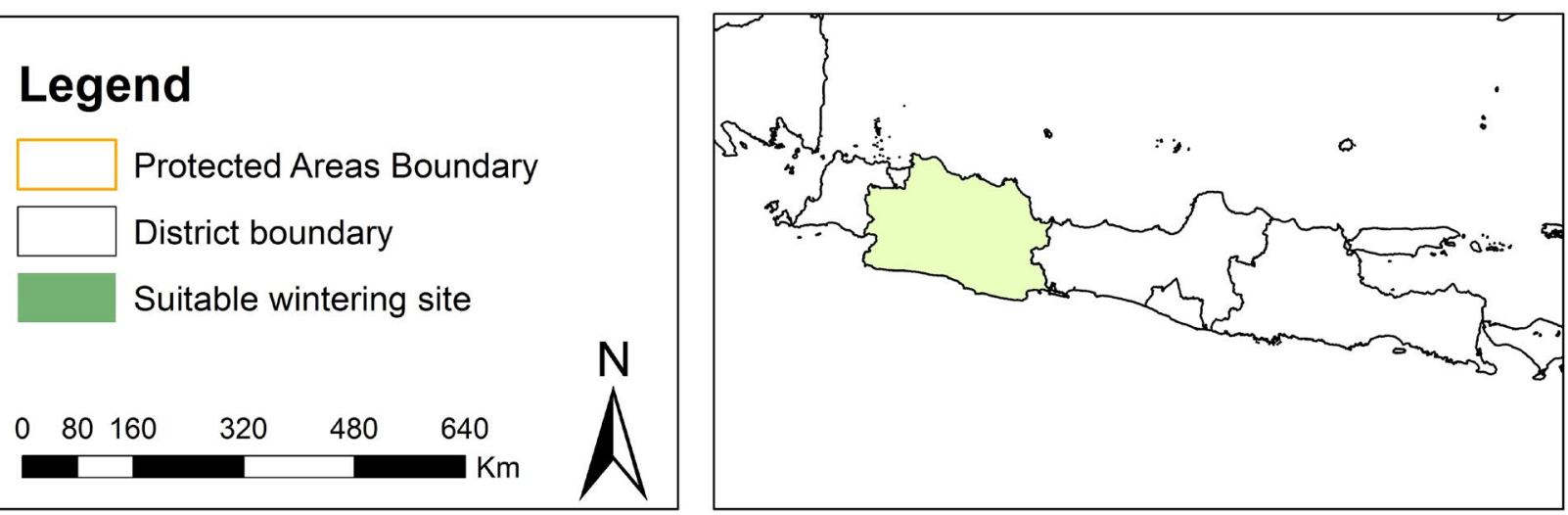

Figure 4. Probability model of the wintering habitat distribution of OHBs, which is extrapolated to West Java 
Table 3. Suitable patches overlaid in protected areas in West Java, Indonesia

\begin{tabular}{llr}
\hline Suitable patch & Protected area type & Protected area inside the suitable patch $\left(\mathrm{Km}^{2}\right)$ \\
\hline Gunung Tangkuban Parahu & Nature Reserve & 6.00 \\
Junghun & Nature Reserve & 0.01 \\
Telaga Warna & Nature Recreation Park & 0.05 \\
Gunung Tangkuban Parahu & Nature Recreation Park & 2.90 \\
Gunung Palasari & Grand Forest Park & 0.35 \\
Tahura Ir. H. Juanda & Grand Forest Park & 3.13 \\
Gunung Burangrang & Nature Reserve & 20.40 \\
Gunung Tampomas & Nature Recreation Park & 3.54 \\
Telaga Warna & Nature Reserve & 5.01 \\
Jember & Nature Recreation Park & 0.52 \\
Gunung Tilu & Nature Reserve & 1.22 \\
Gunung Sawal & Wildlife Reserve & 2.08 \\
Kawah Kamojang & Nature Reserve & 0.17 \\
Gunung Masigit Kareumbi & Game Reserve & 103.37 \\
Gunung Gede - Pangrango & National Park & 26.72 \\
Gunung Pancar & Nature Recreation Park & 4.10 \\
Total & & 179.57
\end{tabular}

\section{Discussion}

\subsection{Landscape Characteristics of Wintering Habitat}

The results of this study are consistent with those of a previous study, which used factor analysis to determine the landscape characteristics of the OHB wintering habitat in Borneo (Syartinilia et al. 2015). The environmental variables that characterize the wintering habitat of OHBs in this study are identical to those found in the core and edge wintering habitat in Borneo. Six of the seven variables identified in this study were included in the first and second-factor analyzes of important landscape characteristics in Borneo (Table 4). Meanwhile, one character remains, namely the nearest distance to a water body that is not included in Borneo's first and second factors but was identified in this study. So, it can be seen that the logistic regression method encourages a better understanding of the landscape characteristics. This result is aligned with the previous studies which are successfully characterizing the habitat of northern pygmy owls (Piorecky and Prescott 2006), migratory fish (Alves and Fontoura 2009; Barradas et al. 2012), Sumatran tiger (Priatna 2020) and african primate (Bracebridge et al. 2011).

The advantages of our approach are as follows. (1) It clearly defines the landscape characteristics based on the contribution of each environmental variable, as reflected in the regression coefficient of each variable; thus, interpreting results using the proposed approach is easier compared with factor analysis, which requires interpreting a new principal component. (2) Our approach can produce a spatial model through spatial modeling approach by directly employing the model equation. (3) Once the model is validated, it can be extrapolated on a larger scale. However, one consideration in applying GLMs within a GIS is determining the presence and absence data. Given the abundance of the presence data from satellite tracking, care must be taken while generating the pseudoabsence data to avoid commission/omission errors. This study have demonstrated how to generate pseudoabsence data for a region that has been delineated using assumptions based on the characteristics of the target species.

OHBs tend to prefer wintering habitat based on the abundance of food and the availability of thermal wind in both the core and edge habitats in Borneo (Syartinilia et al. 2015). We found that similar landscape characteristics, which indicate the availability of these resources, were found in Talaga Bodas and its surrounding areas. Soaring is the predominant migratory flight mode in many large birds (Hedenström 1993; Spaar 1997), including OHBs (Pramono et al. 2015), which use the columns of warm rising air, i.e., thermals, to gain lift (Kerlinger and Gauthreaux 1985; Kerlinger 1989; Leshem and YomTov 1996; Pennycuick 1998). When OHBs travel long distances over the land, they usually alternate soaring on updrafts with gliding to reduce energy-consuming flapping (Higuchi 2014). In term of how raptor utilize the thermal wind during migration also found in European honey buzzards glide between thermals to the migration routes they choose during each season (Vansteelant 2016) and they also have specific respond in order to exploit the thermal wind based on different times and places during their movement (Michele et al. 2016). The variations in elevation and slope, which are expressed in terms of terrain, combined with the favorable weather, generate 
Table 4. Landscape characteristics comparisons resulted from this study compared with a study in Borneo

\begin{tabular}{|c|c|c|c|c|c|}
\hline \multirow{3}{*}{ Environmental variable } & \multirow{3}{*}{ This study } & \multicolumn{4}{|c|}{ Study in Borneo } \\
\hline & & \multicolumn{2}{|c|}{ Core habitat } & \multicolumn{2}{|c|}{ Edge habitat } \\
\hline & & Factor 1 & Factor 2 & Factor 1 & Factor 2 \\
\hline \multicolumn{6}{|c|}{ Nearest distance to the elevation: $0-100 \mathrm{~m}^{*}$} \\
\hline \multicolumn{6}{|c|}{ Nearest distance to the elevation: $100-300 \mathrm{~m}^{*}$} \\
\hline \multicolumn{6}{|c|}{ Nearest distance to the elevation: $300-500 \mathrm{~m}$} \\
\hline \multicolumn{6}{|c|}{ Nearest distance to the elevation: $500-700 \mathrm{~m}$} \\
\hline \multicolumn{6}{|c|}{ Nearest distance to the elevation: $700-1,000 \mathrm{~m}$} \\
\hline \multicolumn{6}{|c|}{ Nearest distance to the elevation: $>1,000 \mathrm{~m}^{*}$} \\
\hline \multicolumn{6}{|c|}{ Nearest distance to the slope: $0-3 \%$} \\
\hline \multicolumn{6}{|l|}{ Nearest distance to the slope: $3-8 \%$} \\
\hline \multicolumn{6}{|l|}{ Nearest distance to the slope: $8-15 \%$} \\
\hline \multicolumn{6}{|l|}{ Nearest distance to the slope: $15-25 \%$} \\
\hline \multicolumn{6}{|l|}{ Nearest distance to the slope: $25-40 \%^{*}$} \\
\hline \multicolumn{6}{|l|}{ Nearest distance to the slope: $>40 \%$} \\
\hline \multicolumn{6}{|l|}{ Nearest distance to the water body } \\
\hline \multicolumn{6}{|l|}{ Nearest distance to the paddy field* } \\
\hline \multicolumn{6}{|l|}{ Nearest distance to the dryland farming } \\
\hline \multicolumn{6}{|l|}{ Nearest distance to the build-up area } \\
\hline \multicolumn{6}{|l|}{ Nearest distance to the shrub } \\
\hline \multicolumn{6}{|l|}{ Nearest distance to the plantation } \\
\hline \multicolumn{6}{|l|}{ Nearest distance to the forest* } \\
\hline \multicolumn{6}{|l|}{ Nearest distance to the bare land } \\
\hline Nearest distance to the swamp bush & & & & & \\
\hline
\end{tabular}

Study in Borneo (Syartinilia et al. 2015); *show the overlap characteristics found in both studies

terrain updrafts, which are the primary source of lift for raptor migration (Brandes and Ombalski 2004: ARRCN 2012). In terms of terrain conductivity calculation, elevation and slope are important components for relative updraft strength (Brandes and Ombalski 2004), both of which are mainly demonstrated to be significant environmental variables in this study.

Food abundance in an area is related to the availability of hunting area for OHBs. In this study, we found that the nearest distance to a forest (DFT) was an important landscape characteristic for the wintering habitat of OHBs. Forest was an important land cover type in the core and edge habitats, where the main food source for OHBs was available (Syartinilia et al. 2015, 2017). The habitat preference of OHBs was significantly related to the existence of bee and wasp colonies (Yang et al. 2015; Ziesemer and Meyburg 2015 ) in the breeding or wintering areas. Apis dorsata was the most common honeybee found in our study area and previous study areas in South Kalimantan (Syartinilia et al. 2015) and Flores (Syartinilia et al. 2017). Apis dorsata usually establishes colonies in areas that have sufficient availability of food, particularly in forests and those surrounded by other vegetated areas. In the study area, Calliandra (Calliandra callothyrsus) has been found dominant in every level of strata based on vegetation analysis (Ameliawati et al. 2013). According to Kartasubrata (1996), Calliandra is planted by farmers in Java to produce good-quality honey, while Behera et al. (2014) found that Calliandra is one of the favorite plants visited by honeybees in India.

Based on previous research results on the habitat of OHBs in Indonesia even in wintering or stopover sites, including Borneo (Syartinilia et al. 2015), Belitung (Mardiyanto et al. 2015), Rupat (Pramono et al. 2015), and Flores (Syartinilia et al. 2017), we found that OHBs require a combination of forest and vegetated areas for their foraging sites. These conditions certainly showed that variation in land cover types is a considerably important aspect. The variations in land cover types in terms of landscape attributes result in heterogeneity, which has an important role in the ecological system. Heterogeneity can be described as the spatial complexity of a landscape mosaic (Farina 2006).

Furthermore, the characteristics of the wintering habitat found in Indonesia resemble the Satoyama landscape in the breeding habitat of OHBs in Japan. Satoyama, a mosaic of paddy fields, woodlands, grass fields, streams, and hills, is an artificially maintained environment that is estimated to represent $40 \%$ of Japan. It is located between mountains and urban areas, where people have lived in harmony with nature. It is also a home to many different birds (Higuchi 2014). Similar habitat characteristics are found in the wintering 
habitat of Talaga Bodas and its surrounding areas. However, a more thorough study on this presumed similarity needs to be conducted because there might be other characteristics required by the OHBs in their breeding areas in Japan.

\subsection{Model Implication for Managing OHB Wintering Habitat in West Java}

Migratory raptors play an important role as an indicator species for rapidly assessing the stability of ecosystems on a global scale. The presence of OHBs that annually migrate to their habitat in Indonesia is an indicator of the health of the ecosystem with respect to their wintering sites and migration routes. Therefore, modeling habitat use and habitat distribution are important for developing conservation plans. The main result of this study is the successful prediction of a probability model with the aid of satellite tracking data for the wintering habitat distribution of OHBs, which is extrapolated to West Java. Although satellite data were derived from only 1 individual $\mathrm{OHB}$, the data may be representative of an OHB flock as raptors always migrate in flocks (Ferguson and Christie 2005) which is consisted till hundreds OHBs. The LR-based spatial modeling approach used herein provides another potential for the use of satellite tracking data to generate a potential habitat distribution model for larger scales. These approaches can be used for investigating other migratory species that have been tracked using satellite or other navigation technologies. Given the expensive satellite tracking technology, a multiscale spatial modeling approach can be developed to support the activities conducted for the conservation of migratory species.

In conclusion, this spatial model was locally constructed from the data concerning Talaga Bodas and its surrounding areas and extrapolated for the entire West Java region. The best predicted probability model successfully characterized the distribution of the OHB wintering habitat using slope (25-40\%), elevation (0-300 $\mathrm{m}$ and $>1,000 \mathrm{~m})$, and land cover (forest, paddy field, and water body). The extrapolation model generated potential areas of the wintering habitat distribution covering an area of $3013.13 \mathrm{~km}^{2}$ ( $8.11 \%$ of West Java). These areas were predominantly located outside the protected areas (94.04\%). The modeling approach proposed herein may be used to study other migratory species that are tracked using satellite or other navigation technologies. Given the abundance of the presence data from satellite tracking, care must be taken while generating the pseudo- absence data to avoid commission/omission errors. The extrapolated predicted probability distribution model that is encompasses protected areas have succeeded in determining locations that are required priority for conducting habitat conservation activities. The GIS approach undertaken herein provides a great opportunity for further analysis of the probability model generated in this study. Therefore, the proposed probability model can serve as a baseline for performing overlay analysis using other spatial data that are owned by decision makers or area managers.

\section{Acknowledgements}

We would like to express our sincere thanks to Raptor Indonesia (RAIN), particularly to Zaini Rakhman for providing guidance during field surveys. Additionally, we would like to express our special thanks to our students Presti Ameliawati and Cici Nurfatimah for providing help in this research. This work was supported by the Ministry of the Environment, Japan, (Hiraikeiro-kaimeichosa, fiscal year 2003-2015) and the Ministry of Research, Technology and Higher Education (RISTEKDIKTI), Indonesia (grant number 011/SP2H/LT/ DRPM/VIII/2017, fiscal year of 2016-2017).

\section{References}

Akcakaya, H.R., Root, W., 2002. RAMAS GIS: Linking Spatial Data with Population Viability Analysis (Version 4.0). Applied biomethematics: New York.

Alves, T.P., Fontoura, N.F., 2009. Statistical distribution models for migratory fish in Jacuí basin. South Brazil. Neotropical Ichthyology. 7, 647-658. https:// doi.org/10.1590/S1679-62252009000400014

Ameliawati, P., Syartinilia, Mulyani, Y.A., 2013. Karakteristik habitat musim dingin sikep madu asia (Pernis ptylorhynchus) di Talaga Bodas, Jawa Barat Berbasis data satellite tracking. Jurnal Lanskap Indonesia. 5, 3742. DOI:10.29244/jli.2013.5.2.37-42

Argos., 2016. User's manual, CLS/Service Argos, Maryland. Available at: http://www.argos-system.org/wpcontent/uploads/2016/08/r363_9_argos_users manual-v1.6.6.pdf [Date accessed: 11 January 2017)

[ARRCN] The Asian Raptor Research and Conservation Network. 2012. Field Guide to raptors of Asia Vol. 1: Migratory Raptors of Oriental Asia. Japan: Asian Raptors Research and Conservation Network.

Bailey, S.A., Haines-Young, R.H., Watkins, C., 2002. Species presence in fragmented landscape: modeling of species requirements at the national level. Biol. Cons. 108, 307-316. https://doi.org/10.1016/S00063207(02)00119-2

Barradas, J.R.S., Silva, L.G., Harvey, B.C., Fontoura, N.F., 2012. Estimating migratory fish distribution from altitude and basin area: a case study in a large Neotropical river. Freshwater. Biol. 57, 2297-2305. https://doi. org/10.1111/fwb.12003 
Behera, L.K., Mehta, A.A., Sinha, S.K., 2014. Suitable bee flora availability for commercial apiculture during dearth period in the heavy rainfall zone of South Gujarat. Res. J. Chem. Env. Sci. 2, 65-68.

Bildstein, K.L., 2006. Migrating Raptor of the World: Their Conservation and Ecology. Cornell University Press: New York.

Boone, R.B., Krohn, W., 1999. Modeling the occurrence of bird species: are the errors predictable?. Ecol. Appl. 9, 835-848. https://doi.org/10.1890/10510761(1999)009[0835:MTOOBS]2.0.CO;2

Bracebridge, C.E., Davenport, T.R.B., Marsden, S.J., 2011. Can we extend the area of occupancy of the kipunji, a critically endangered African primate?. Animal Conservation. 14, 687-696. https://doi.org/10.1111/ j.1469-1795.2011.00474.x

Brandes, D., Ombalski, D.W., 2004. Modeling raptor migration pathways using a fluid-flow analogy.J. Raptor. Res. 38, 195-207.

Bruderer, B., Blitzblau, S., Peter, D., 1994. Migration and flight behavior of honey buzzards (Pernis apivorus) in Southern Israel, observed by radar. ARDEA. 82, $111-122$

Cohn, J.P., 1999. Tracking wildlife: High-tech devices help biologists trace the movement of animals through sky and sea. Bio. Sci. 49, 12-17.

Engler, R., Guisan, A., Rechsteiner, L., 2004. An improved approach for predicting the distribution of rare and endangered species from occurrence and pseudoabsence. J. Appl. Ecol. 41, 263-274. https://doi. org/10.1111/j.0021-8901.2004.00881.x

Farina, A., 2006. Principles and Methods in Landscape Ecology: Toward a Science of Landscape. Springer: United States.

Ferguson, J., Christie, D., 2005. Raptors of the World. Black Publisher: London.

Germi, F., 2005. Raptor migration in east Bali, Indonesia: observations from a bottleneck watch site. Forktail. 21, 93-98.

Guisan, A., Edwards, T.C., Hastie, T., 2002. Generalized linear and generalized additive models in studies of species distributions: setting the scene. Ecol. Model. 157, 89100. https://doi.org/10.1016/S0304-3800(02)00204-1

Hedenström, A., 1993. Migration by soaring or flapping flight in birds: the relative importance of energy cost and speed. Philos. Trans. R. Soc. B. Biol. Sci. 342, 353-361. https://doi.org/10.1098/rstb.1993.0164

Higuchi, H., Shiu, H.J., Nakamura, H., Uematsu, A., Kuno, K., Saeki, M., Hotta, M., Tokita, K.I., Moriya, E., Morishima, E., Tamura, M., 2005. Migration of honey buzzards Pernis apivorus based on satellite tracking. Ornithol. Sci. 4, 109-115. https://doi.org/10.2326/osj.4.109

Higuchi, H., Pierre, J.P., 2005. Satellite tracking and avian conservation in Asia. Landsc. Ecol. Eng. 1, 33-42. https://doi.org/10.1007/s11355-005-0002-4

Higuchi, H., 2014. Natural history of Japanese birds. Heibonsha, Tokyo. Available at: http://www.heibonsha.co.jp/ files/JapaneseBirds_E_v4_0825.pdf (Date accessed: 25 November 2017)

Hirzel, A.H., Helfer, V., Metral, F., 2001. Assessing habitat suitability models with a virtual species. Ecol. Model. 145, 111-121. https://doi.org/10.1016/S03043800(01)00396-9

Hosmer, D.W., Hosmer, T., Le Cessie, S., Lemeshow, S., 1997. A comparison of goodness-of-fit tests for the logistic regression model. Stat. Med. 16, 965-980. https://doi.org/10.1002/(SICI)10970258(19970515)16:9<965::AID-SIM509>3.0.CO;2-O

Huang, J., Frimpong, E.A., 2015. Using historical atlas data to develop high-resolution distribution models of freshwater fishes. PLoS One. 10, 1-19. https://doi. org/10.1371/journal.pone.0129995
Hutto, R.L., 1985. Habitat selection by non-breeding, migratory land bird. In: Cody ML (Eds.). Habitat Selection in Birds. New York: Academic Press. pp. 455-476.

Kartasubrata, J., 1996. Culture and Uses of Calliandra calothyrsus in Indonesia. In: Proceedings of International Workshop in the Genus Calliandra. Forest, Farm and Community Tree Research Reports (Special Issue). Morrilton Arkansas USA: Winrock International. pp. 101-107.

Kenward, R.E., Clarke, R.T., Hodder, K.H., Walls, S.S., 2001. Density and linkage estimates of home range: nearestneighbor clustering defines multinuclear cores. Ecology. 82, 1905-1920. https://doi.org/10.1890/00129658(2001)082[1905:DALEOH]2.0.CO;2

Kerlinger, P., 1989. Flight Strategies of Migrating Hawks. University of Chicago Press: Chicago.

Kerlinger, P., Gauthreaux, S.A., 1985. Flight behavior of raptors during spring migration in South Texas studied with radar and visual observations. J. Field. Ornithol. 56, 94-402.

Leshem, Y., Yom-Tov, Y., 1996. The use of thermals by soaring migrants. Ibis. 138, 667-674. https://doi.org/10.1111/ j.1474-919X.1996.tb04768.x

Lyons, A.L., Gaines, W.L., Servheen, C., 2003. Black bear resource selection in the northeast Cascades, Washington. Biol. Cons. 113, 55-62. https://doi. org/10.1016/S0006-3207(02)00349-X

Mardiyanto, A., Syartinilia, Makalew, A.D.N., Higuchi, H., 2015 Spatial distribution model of stopover habitats used by Oriental Honey Buzzards in East Belitung based on satellite-tracking data. Procedia. Environ. Sci. 24, 95-103. https://doi.org/10.1016/j.proenv.2015.03.013

Mace, R.D., Waller, J.S., Manley, T.L., Lyon, L.J., Zuuring, H. 1996. Relationships among grizzly bears, roads and habitat in the Swan Mountains Montana.J.Appl. Ecol. 33, 1395-1404. https://doi.org/10.2307/2404779

Mace, R.D., Waller, J.S., 1997. Spatial and temporal interaction of male and female grizzly bears in Northwestern Montana. J. Wildl. Manage. 61, 39-52. https://doi. org/10.2307/3802412

Manel, S., Dias, J.M., Ormerod, S.J., 1999. Comparing discriminant analysis, neural networks and logistic regression for predicting species distributions: a case study with a Himalayan river bird. Ecol. Model. 120, 337-347. https://doi.org/10.1016/S03043800(99)00113-1

McLoughlin, P.D., Case, R.L., Gau, R.J., Cluff, D.H., Mulders, R., Messier, F., 2002. Hierarchical habitat selection by barren-ground grizzly bears in the central Canadian Arctic. Ecosyst. Ecol. 132, 102-108. https://doi. org/10.1007/s00442-002-0941-5

Merow, C., Smith, M.J., Silander, J.A., 2013. A practical guide to MaxEnt for modeling species' distributions: what it does, and why inputs and settings matter. Ecography. 36, 1058-1069. https://doi.org/10.1111/j.16000587.2013.07872.x

Michele, P., Viviana, S., Carlo, C., Mauro, S., Giacomo, D. 2016. Radar tracking reveals influence of crosswinds and topography on migratory behavior of European honey buzzards. J. Ethol. 34, 73-77. https://doi.org/10.1007/ s10164-015-0448-2

Ornithological Society of Japan., 2000. Check-list of Japanese Birds, sixth ed. Ornithological Society of Japan: Obihiro.

Ottaviani, D., Lasinio, G.J., Boitani, L., 2004. Two statistical methods to validate habitat suitability models using presence only data. Ecol. Model. 179, 417-443. https:// doi.org/10.1016/j.ecolmodel.2004.05.016

Pearce, J.L., Boyce, M.S., 2006. Modeling distribution and abundance with presence-only data. J. Appl. Ecol. 43, 405-412. https://doi.org/10.1111/j.13652664.2005.01112.x 
Peng, C.J., Lee, K.L., Ingersoll, G.M., 2002. An introduction to logistic regressionanalysisand reporting.J.Educ. Res. 96, 3-14. https://doi.org/10.1080/00220670209598786

Pennycuick, C.J., 1998. Field observations of thermals and thermal streets, and the theory of cross-country soaring flight. J. Avian. Biol. 29, 33-43. ttps://doi. org/10.2307/3677338

Phillips, S.J., Dudik, M., 2008. Modeling of species distributions with maxent: new extensions and a comprehensive evaluation. Ecography. 31, 161-175. https://doi. org/10.1111/j.0906-7590.2008.5203.x

Phillips, S.J., Anderson, R.P., Dudík, M., Schapire, R.E., Blair, M.E., 2017. Opening the black box: an open-source release of maxent. Ecography. 40, 887-893. https:// doi.org/10.1111/ecog.03049

Piorecky, M.D., Prescott, D.R.C., 2006. Multiple spatial scale logistic and autologistic habitat selection models for northern pygmy owls, along the eastern slopes of Alberta's Rocky Mountains. Biol. Cons. 129, 360-371. https://doi.org/10.1016/j.biocon.2005.11.003

Pramono, H., Mulyani, Y.A., Syartinilia, Higuchi, H., 2015. Pemodelan distribusi kesesuaian habitat singgah Sikep Madu Asia (Pernis ptilorhynchus) di pulau Rupat berdasarkan data satellite-tracking. Media Konservasi. 20, 61-67.

Priatna, D., 2020. Habitat suitability model to determine a suitable area for translocation of sumatran tiger (Panthera tigris sumatrae Pocock 1929). Asian Journal of Conservation Biology. 9, 39-55.

Seaman, D.E., Powell, R.W., 1996. An evaluation of the accuracy of kernel density estimators for homerange analysis. Ecology. 77, 2075-2085. https://doi. org/10.2307/2265701

Spaar, R., 1997, Flight strategies of migrating raptors: a comparative study of interspecific variation in flight characteristics. Ibis. 139, 523-535. https://doi. org/10.1111/j.1474-919X.1997.tb04669.x

Stockwell, D.R.B., Peterson, A.T., 2002a. Controlling bias in biodiversity. In: Scott MS, Heglund PJ, Morrison M (Eds.). Predicting Species Occurrences: Issues of Accuracy and Scale. Island Press: Washington. pp. 537-546.

Stockwell, D.R.B., Peterson, A.T., 2002b. Effects of sample size on accuracy of species distribution models. Ecol. Model. 148, 1-13. https://doi.org/10.1016/S03043800(01)00388-X
Syartinilia, Tsuyuki, S., 2008. GIS-based modeling of Javan hawk-eagle distribution using logistic and autologistic regression models. Biol. Cons. 141, 756-769. https:// doi.org/10.1016/j.biocon.2007.12.030

Syartinilia, Makalew, A.D.N., Mulyani, Y.A., Higuchi, H., 2015 Landscape characteristics of wintering habitats used by Oriental Honey Buzzards in Borneo derived from satellite tracking data. Landsc. Ecol. Eng. 11, 61-71. https://doi.org/10.1007/s11355-013-0237-4

Syartinilia, Al farisi, G.H., Higuchi, H., 2017. Landscape characteristics of Oriental Honey Buzzards wintering in western part of Flores Island based on satellite-tracking data. IOP. Conf. Ser: Earth. Environ. Sci. 91, 012031. https://doi.org/10.1088/1755$1315 / 91 / 1 / 012031$

Vansteelant, W.M.G., 2016. From Thermal to Flyway: How Weather Shapes the Soaring Migration of European Honey Buzzards Pernis Apivorus at Multiple Scales [Dissertation]. Amsterdam, Netherlands: University of Amsterdam.

Wauters, L.A., Preatoni, D.G., Molinari, A., Tosi, G., 2007. Radio-tracking squirrels: performance of home range density and linkage estimators with small range and sample size. Ecol. Model. 202, 333-344. https://doi. org/10.1016/j.ecolmodel.2006.11.001

Webster, M.S., Marra, P.P., Haig, S.M., Bensch, S., Holmes, R.T., 2002. Links between worlds: unraveling migratory connectivity. Trends. Ecol. Evol. 17, 76-78. https://doi. org/10.1016/S0169-5347(01)02380-1

Worton, B.J., 1989. Kernel methods for estimating the utilization distribution in home-range studies. Ecology. 70, 164-168. https://doi.org/10.2307/1938423

Yang, S.Y., Walther, B.A., Weng, G.J., 2015. Stop and smell the pollen: The role of olfaction and vision of the Oriental Honey Buzzard in identifying food. PLoS One. 10, 1-18. https://doi.org/10.1371/journal.pone.0130191

Zalles, J.I., Bildstein, K.L., 2000. Raptor Watch: A Global Directory of Raptor Migration Sites. Cambridge: BirdLife International.

Zaniewski, A.E., Lehmann, A., Overton, J.M., 2002. Predicting species spatial distributions using presence-only data: a case study of native New Zealand ferns. Ecol. Model. 157, 261-280. https://doi.org/10.1016/S03043800(02)00199-0

Ziesemer, F., Meyburg, B.U., 2015. Home range, habitat use and diet of Honey-buzzards during the breeding season. British. Birds. 108, 467-481. 